\title{
The Effect of Resources Capabilities on Cross Functional Coordination in the Footwear Micro Industry in West Jawa
}

\author{
Utang Jujur \\ Universitas Padjadjaran, Bandung, Indonesia
}

\begin{abstract}
This study is aimed at analyzing resources capabilities and cross functional coordination, and recognizes the effect of resources capabilities on cross functional coordination in the footwear micro industry in West Jawa. The author conducted descriptive survey and quatitative study to determine the level of relationship of different variables on population and to measure the contribution of free variables to restricted variables. The result shows that the resources capabilities, including leather raw materials, synthetic raw materials, funding, human resources, science management, and information and technology influence cross functional coordination in footwear micro industry in West Jawa. This study also reveals that significant resources capabilities elements include leather raw materials, funding, and human resources supplies, while other elements provided insignificant impact.
\end{abstract}

Keywords: resources capabilities, cross functional coordination, MSME, footwear

\section{Introduction}

The number of MSME in the world has been growing. However, their competitiveness edge is still relatively weak, both in domestic and international markets. This situation also applies in Indonesia. Most of MSMEs in Indonesia focus more on production processes, and less on marketing and product competitiveness. Wilantara and Susilawati (2016) revealed that approximately 70\% of the existing MSMEs in Indonesia were established for only income generation. The business commencement was not motivated by distinctive products nor the talent on certain aspects. Consequently, MSME's product cannot compete well with those of large companies.

Wilantara and Susilawati (2016) state that small industry development has an important role in developing manufacturing industries. The development of small scale industries will help solve unemployment issues in the sense that technology used is a labor intensive technology. It can enlarge employment and business opportunities, and encourage local development.

According to Indonesian Beaureauof Statistic, the number of MSME in 2016 has reached 42.9 million business units or $99.9 \%$ from the total business units nationwide. The potential of employment in the sector is also very high. It can absorb about $99.4 \%$ of the total national workforce. In addition, MSME significantly contributed to Gross National Products (GNP/PDB), i.e., 56.72\%.

Utang Jujur, MS, Doctorate School of Management and Business, the leader of the business association, Universitas Padjadjaran, Bandung, Indonesia.

Correspondence concerning this article should be addressed to Utang Jujur, Doctorate School of Management and Business, University Padjadjaran, JalanDipatiukur no. 46, 40132, Bandung, Indonesia. 
Some problems faced by MSME in footwear sector are also common problems to MSME in other sectors. The problems include poor access to funding, inadequate production technology, limited access to raw materials and market, instable price of raw materials, occasional non-standard raw materials, as well as insufficient skilled workforce. These problems are much related to resources capabilities aspects, cross functional coordination gap in planning business strategies that affect business performance of footwear MSMEs.

The author conducted a pre-survey on 190 respondents of footwear MSMEs in West Jawa. The survey results show that supplies of raw materials only fulfill 59.5\% of the raw materials need and the government role in alleviating this obstacle is less significant. Other issues include inadequate funding. The business owners tend to get extremely expensive fund from informal (private) loan provider, locally known as "ijon". The other revealed problem is the absence of standard organizational structure and working unit in the MSMEs. Finally, the survey discovered that low quality and product design have lowered their product competitiveness.

Based on the above description, this study tries to reveal: i) the magnitude of resource capabilities and cross functional coordination in footwear micro industry in West Jawa, and ii) the influence of resources capabilities toward cross functional coordination in footwear micro industry in West Jawa.

\section{Literature Review}

\section{Resources Capabilities}

Developing competitive advantage through development and distribution of resources and capabilities becomes the main goal to develop a more successful business strategy (Grant, 2010). Resources are combined resource skills of the company and determine what company can do (Collins \& Montgomery, 2005). Capabilities are subset organization resources and defined as tangible and intangible assets that enable organization to take full advantages from other controlled resources (Barney \& Hesterly, 2012).

\section{Cross Functional Coordination}

The focus of an organization is how in practice to explore various business functions work under command and direction of top management to ensure that the applied system supports cross functional business processes and create competitive advantage (Sanjay, Lee, \& Kim, 2005).

According to Porter (2012), the idea to combine a number of different but related businesses can create a value through a vastly accepted synergy and confirm a largely diversified verification. This development has made a horizontal strategy, to cut all boundaries on divisions and working units, and perhaps become the most important agenda on a diversified organizational strategy. In functional area, it is crucial to strengthen competitive advantage, knowledge, and management experience that are considered as important resources and cannot be imitated by competitors (Aaker, 2004; Barney, 2011; Penrose, 1959).

A study by Muthusamy, Kanagarajan, and Ponnusamy (2008) shows that cross functional coordination capabilities, i.e., Coordinating Operation, Engineering, Coordinating Operation, and Marketing and Coordinating Operation, and Purchasing in organizations are three significant dimensions on coordination capabilities in organization. Furthermore, the study also shows that there is a positive relationship among capabilities coordination in organization and Product Quality Improvement (PQI) and they confirm a positive relationship between PQI and financial performance.

\section{Theoretical Framework}

In footwear industries, there are 21 raw material items that make a pair of footwear. Moreover it also 
needs resources and capabilities coordination to make products have competitive advantage. Competitive advantage can be understood only by considering organizations as a whole organization. Competitive advantage is made from many different activities from each business unit that is done by organizations in designing, producing, marketing, delivering, and supporting their productions (Porter, 2008). Each business unit activity can support the making of relative cost position and create base of differentiation.

Resources capabilities are strategic activities to prepare production requirements for high quality products. It can be seen from raw materials, financial aspect, knowledge and resources skills, and also supporting information and technology. Analysis on resources and capabilities enables decision makers to assess organizational competitive assets and to determine organization basic needs to be successful in the market. There are two steps to analyze this: (1) identifying organizational resources and capabilities so that managers can have better ideas to develop organizational competitive plans; (2) examining further organizational resources and capabilities to ensure which of those has the most competitive value and to determine the best way to help organization achieve further competitive advantage.

In resources capabilities and cross functional coordination, it will automatically integrate various employee backgrounds, knowledge, and skills in teamwork structure. Therefore, using a team that consists of members coming from different skills and backgrounds becomes developing practice in modern organizations. Diversity in a team, however, creates opportunities and challenges. If they are managed well, heterogeneity can create a significant operational synergy, while diversity of mismanaged team can become large barriers to function optimally due to intergroup conflicts, miscommunication, and lack of trusts. Many researchers agree that effective application on cross functional coordination is very crucial to effectively develop new products (Man, 2009).

Cross functional coordination is crucial in every organization as it enables perfect integration of work, organizational vision and mission implementation, and shared commitment and effective team work. Therefore, coordination processes among functional units may need significant efforts in practice because of many organizational failures in achieving their goals due to difficulties in applying cross functional coordination (Sanjay, Lee, \& Kim, 2005). The research paradigm can be seen in Figure 1 below:

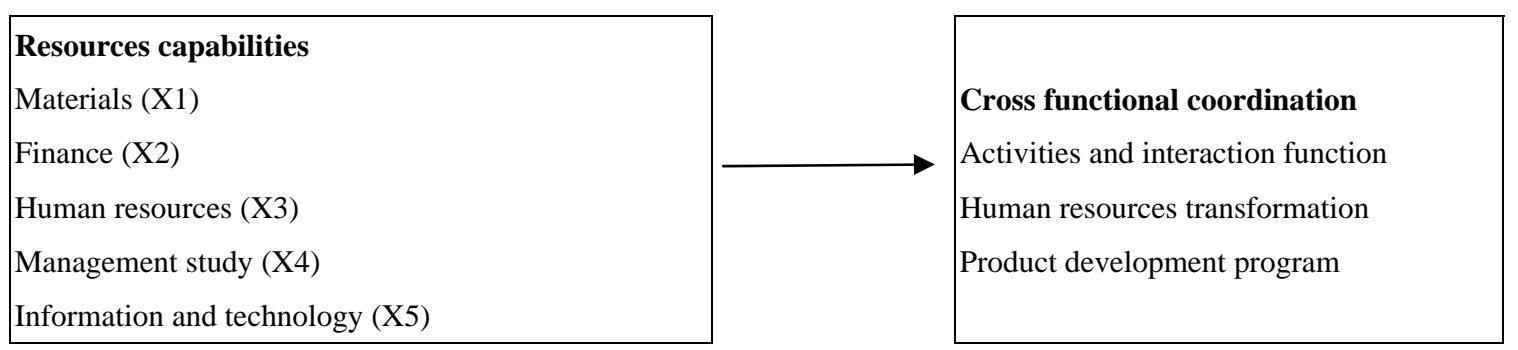

Figure 1. Research paradigm.

\section{Research Methods}

This study applies Path Analysis to answer the research questions. In this study, the author observes i) independent variable, i.e., resources capabilities; and ii) dependent variables, i.e., cross functional coordination. The primary data were collected through a questionnaire, which was distributed to footwear micro business owners in West Jawa. Population in this study includes the footwear micro business players in West Jawa. The author employs stratified random sampling, and ends up with 200 analysis units. Collecting sample from every 
stratum was done proportionally, which took equal number of samples in every stratum. The author conducts validity test on the questionnaire and reliability test to assess accountability of measurement tool.

\section{Discussions}

\section{Validity Test and Reliability Test}

The validity test examines items on each variable and finds that they are valid, since the value of $r$ is higher than 0.3. The results of reliability test show that the values of cronbachalpha of resources capabilities and cross functional coordination are 0.880 and 0.752, consecutively. As they are larger than 0.7, the questionnaire of resources capabilities and cross functional coordination is reliable.

\section{Resources Capabilities}

The total score of resources capabilities that were assessed through materials, finance, human resources, management study, and also information and technology is 26,371, which is good enough. This is due to lack of government intervention to ensure raw materials supplies and to control leather prices in the market. From the financial perspective, MSME cannot ensure sustainability of their production due to insufficient working capital. The businesses also find difficult to get appropriate operation staff. Moreover, the MSME actors really need management and technical trainings to help them improve their business performance.

\section{Cross Functional Coordination}

The total score of cross functional coordination, which is assessed through functional activities and interactions, human resources transformation, and product development programs, is 9,806 (good enough). Efforts to pass on skills do not work well. Number of skilled staffs decreases. Footwear MSME in West Jawa has not yet had product development program unit and the government has not optimized the board of specialists to support product research and development.

As for influence of resources capabilities on cross functional coordination in footwear micro industry in West Jawa, Table 1 shows correlation among variables.

Table 1

Matrix of Correlation Between Variables

\begin{tabular}{lllllll}
\hline & $B B K$ & $B B S$ & $P K$ & $P S D M$ & $P I M$ & $P I T$ \\
\hline BBK & 1 & & & & & \\
BBS & 0.671179 & 1 & & & & \\
PK & 0.310622 & 0.292074 & 1 & & & \\
PSDM & 0.523348 & 0.628719 & 0.352606 & 1 & & 1 \\
PIM & 0.413686 & 0.492546 & 0.219902 & 0.580632 & 1 & \\
PIT & 0.192807 & 0.281167 & 0.054032 & 0.249978 & 0.506775 & 1 \\
\hline
\end{tabular}

Source: Data that have been processed.

Proportion for path diagram is two independent variables $(\mathrm{x})$ that have correlation among variables. From multiple regression measurement, it can be seen on Table 2. The iteration process involves four stages. Any varibale with significance level $>0.05$ is excluded from the model.

From Table 2, equation line is obtained as follows:

$$
\begin{gathered}
Y=p_{y x 1} X_{1}+p_{y x 2} X_{2}+p_{y x 3} X_{3}+p_{y e} \varepsilon \\
Y=0.225 X_{1}+0.171 X_{2}+0.511 X_{3}+0.453 \varepsilon
\end{gathered}
$$


According to equation line diagram above, it shows that:

Table 2

Multiple Regression Test Phase 1-4

\begin{tabular}{llll}
\hline Test phase & Model (variables) & $t$ & Sig. \\
\hline \multirow{4}{*}{1} & BBK & 2.81 & 0.01 \\
BBS & 0.62 & 0.54 \\
& PK & 3.18 & 0.00 \\
& PSDM & 6.32 & 0.00 \\
& PIM & 1.53 & 0.13 \\
& PIT & -0.66 & 0.51 \\
& BBK & 3.59 & 0.00 \\
2 & PK & 3.20 & 0.00 \\
& PSDM & 6.96 & 0.00 \\
& PIM & 1.59 & 0.11 \\
& PIT & -0.61 & 0.55 \\
& BBK & 3.59 & 0.00 \\
& PK & 3.24 & 0.00 \\
& PSDM & 7.01 & 0.00 \\
& PIM & 1.48 & 0.14 \\
& BBK & 3.855 & 0.00 \\
& PK & 3.223 & 0.00 \\
\hline
\end{tabular}

Source: Processed data.

- The direct influence on leather raw materials resources (BBK) on cross functional coordination (Y) is as much as 0.2248 , meaning that the direct influence of leather raw materials (XI) on cross functional coordination (Y) is $5.05 \%$.

- The direct influence on finance resources (PK) on cross functional coordination in footwear micro industry in West Jawa $(\mathrm{Y})$ is as much as 0.1712 . This means that the direct influence on finance resources (PK) on cross functional coordination $(\mathrm{Y})$ is as much as $2.93 \%$.

- The direct influence on human resources (SDM) on cross functional coordination in footwear micro industry in West Jawa $(\mathrm{Y})$ is as much as 0.5113 . This means that the direct influence on human resources (SDM) on cross functional coordination ( $\mathrm{Y}$ ) is $26.15 \%$.

- The direct influence on residue on cross functional coordination $(\mathrm{Y})$ is as much as 0.453 . This means that the direct influence on residue on cross functional coordination $(\mathrm{Y})$ is $45.3 \%$.

The direct influence given by variable of leather raw materials resources (BBK) on variable of cross functional coordination $(\mathrm{Y})$ is $5.05 \%$. The value shows the size of influence of leather raw materials resources (BBK) on variable of cross functional coordination (Y) without interfering with other variables.

On the other hand, the influence is indirect, because there is a correlation with other variables, which can be seen on the Tables above. In total, the influence of leather raw materials resources (BBK) on variable of cross functional coordination (Y) is as much as $12.27 \%$ in a positive way, which means the better raw materials resources (BBK), the better cross functional coordination (Y). The influence as much as $12.27 \%$ is categorized as low, which means raw materials resources (BBK) have a low influence on variable of cross functional coordination (Y).

The direct influence given by variable of finance resources (PK) on variable of cross functional coordination $(\mathrm{Y})$ is as much as $2.93 \%$. The value indicates the influence of finance resources $(\mathrm{PK})$ on variable of cross functional coordination (Y) without interfering other variables. 
On the other hand, the influence is indirect, because there is a correlation with other variables, which can be seen on the Tables above. In total, the influence of finance resources (PK) on variable of cross functional coordination (Y) is as much as $7.21 \%$ in a positive way, which means the better finance resources (PK), the better cross functional coordination $(\mathrm{Y})$. The influence as much as $7.21 \%$ is categorized as low, which means finance resources (PK) have a low influence on variable of cross functional coordination (Y).

The direct influence given by variable of human resources (SDM) on variable of cross functional coordination ( $\mathrm{Y}$ ) is as much as $26.15 \%$. The value shows the size of influence of human resources (SDM) on variable of cross functional coordination $(\mathrm{Y})$ without interfering with other variables.

On the other hand, the influence is indirect, because there is a correlation with other variables, which can be seen on the Tables above. In total, the influence of human resources (SDM) on variable of cross functional coordination ( $\mathrm{Y}$ ) is as much as $35.25 \%$ in a positive way, which means the better human resources (SDM), the better cross functional coordination (Y). The influence as much as $35.25 \%$ is categorized as low, which means human resources (SDM) have a low influence on variable of cross functional coordination (Y).

\section{Hypothetical Verifying Test}

Simultaneous test. Whether resources capabilities influence cross functional coordination (Y), a hypothesis testing is done through F-test, with the condition Ho is accepted if $\mathrm{F}_{\text {value }}<\mathrm{F}_{\text {table, }}$ and Ho is rejected if

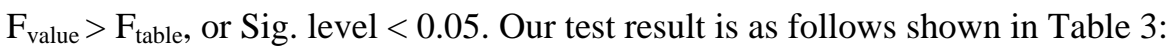

Table 3

Result of Simultaneous Tests

\begin{tabular}{|c|c|c|c|c|c|}
\hline \multicolumn{6}{|c|}{ ANOVA $^{\mathrm{b}}$} \\
\hline Model & Sum of squares & Df & Mean aquare & $\mathrm{F}$ & Sig. \\
\hline Regression & $7,719.324$ & 6 & $1,286.554$ & 38.351 & $0.00^{\mathrm{a}}$ \\
\hline Residual & $6,206.156$ & 185 & 33.547 & & \\
\hline Total & $13,925.479$ & 191 & & & \\
\hline
\end{tabular}

Source: Processed data.

Table 3 shows that resources capabilities influence cross functional coordination. It means that the individual test with hypothesis can be continued.

Partial testing is then done since simultaneous test rejects hypothesis zero. The summary of the partial test can be seen on Table 4 below.

Table 4

Partial Testing-The Hypothesis X1 and X2 on $Y$

\begin{tabular}{|l|l|l|l|}
\hline Path coefficient & $\begin{array}{l}\text { Sig. } \\
\text { level }\end{array}$ & Compare 0.05 & Conclusion \\
\hline Pyx1 & 0.006 & $\leq 0.05$ & $\begin{array}{l}\text { Ho is rejected } \\
\text { Supply of raw materials to blend the skin effect on the cross functional micro } \\
\text { footwear industry in West Jawa }\end{array}$ \\
\hline Pyx2 & 0.538 & $\leq 0.05$ & $\begin{array}{l}\text { Ho accepted } \\
\text { Synthetic leather raw material supply to the blend does not affect the cross } \\
\text { functional micro footwear industry in West Jawa }\end{array}$ \\
\hline Pyx3 & 0.002 & $\leq 0.05$ & $\begin{array}{l}\text { Ho is rejected } \\
\text { Affect the financial supply to blend cross functional micro footwear industry in } \\
\text { West Jawa }\end{array}$ \\
\hline
\end{tabular}


Table 4 continued

\begin{tabular}{|l|l|l|l|}
\hline Path coefficient & $\begin{array}{l}\text { Sig. } \\
\text { level }\end{array}$ & Compare 0.05 & Conclusion \\
\hline Pyx4 & 0.000 & $\leq 0.05$ & $\begin{array}{l}\text { Ho is rejected } \\
\text { Supply of human resources to influence the mix of cross functional micro } \\
\text { footwear industry in West Jawa }\end{array}$ \\
\hline Pyx5 & 0.127 & $\leq 0.05$ & $\begin{array}{l}\text { Ho is accepted } \\
\text { Science does not affect the management of the blend cross functional micro } \\
\text { footwear industry in West Jawa }\end{array}$ \\
\hline Pyx6 & 0.510 & $\leq 0.05$ & $\begin{array}{l}\text { Ho accepted } \\
\text { Information and technology to blend does not affect the cross functional micro } \\
\text { footwear industry in West Jawa }\end{array}$ \\
\hline
\end{tabular}

Source: Calculation results.

\section{Conclusion}

The purpose of this study is to analyze resources capabilities and cross functional coordination, and recognize the effect of resources capabilities on cross functional coordination in the footwear micro industry in West Jawa. The author conducted descriptive survey and path analysis to determine the level of relationship of different variables and to measure the contribution of independent variables to dependent variables. The result shows that the resources capabilities, including leather raw materials, synthetic raw materials, funding, human resources, science management, and information and technology influence cross functional coordination. This study also reveals that significant resources capabilities elements include leather raw materials, funding, and human resources supplies, while other elements provided insignificant impact.

\section{References}

Aaker, A. (2004). Strategic marketing management. New York: John Willey.

Barney, J. B. (2011). Gaining and sustaining competitive advantage (4th ed.). USA: Pearson Education.

Barney, J. B., \& Hesterly, W. S. (2012). Strategic management and competitive advantage (4th ed.). USA: Pearson Education.

Collis, D. J., \& Montgomery, C. A. (2005). Corporate strategy: A resource-based approach (2nd ed.). USA: McGrow-Hill.

Grant, R. M. (2010). Analisis Strategi kewirusahaan konsep, teknik dan aplikasi. Jakarta: Erlangga.

Muthusamy, S., Kanagarajan, S., \& Ponnusamy, S. (2008). Efficiency of RAPD and ISSR marker system in accessing genetic variation of rice bean (Vigna umbellata) landraces. Electronic Journal of Biotechnology, 11(3), 1-8.

Man, M. M. K. (2009). The relationship between distinctive capabilities, innovativeness, strategy types and the performance of small and medium-size enterprises (SMEs) of Malaysian manufacturing sector. International Business \& Economics Research Journal (IBER), 8(11).

Sanjay, G., Lee, Z., \& Kim, Y. (2005). The management of cross-functional inter-dependencies in ERP implementations: Emergent coordination patterns. European Journal of Information Systems, 14(4), 371-387.

Porter, M. E. (2012). Competitive strategy: Techniques for analyzing industries and competitors. New York: The Free Press.

Porter, M. E. (2008). Competitive advantage (Menciptakan dan mempertahankan kinerja unggul). Jakarta: Erlangga.

Wilantara, R. D., \& Susilawati, S. P. (2016). Strategi Kebijakan Pengambangan UMKM, PT. Refika Aditama. 